\title{
Deregulation of microRNA expression in follicular cell-derived human thyroid carcinomas
}

\author{
Pierlorenzo Pallante ${ }^{1,2}$, Rosa Visone ${ }^{1}$, Carlo Maria Croce ${ }^{3}$ and Alfredo Fusco ${ }^{1,2}$
}

\begin{abstract}
${ }^{1}$ Istituto di Endocrinologia ed Oncologia Sperimentale del CNR c/o Dipartimento di Biologia e Patologia Cellulare e Molecolare, Facoltà di Medicina e Chirurgia di Napoli, Università degli Studi di Napoli 'Federico II', Via Pansini 5, 80131 Napoli, Italy ${ }^{2}$ Biotecnologie Avanzate-Napoli, \& SEMM, European School of Molecular Medicine, Naples Site, NOGEC (Naples Oncogenomic Center)-CEINGE, Via Comunale Margherita 482, 80145 Napoli, Italy

${ }^{3}$ Department of Molecular Virology, Immunology, and Medical Genetics, Comprehensive Cancer Center, Ohio State University, 460 West $12^{\text {th }}$ Avenue, 43210 Columbus, Ohio, USA

(Correspondence should be addressed to A Fusco, Istituto di Endocrinologia ed Oncologia Sperimentale del CNR c/o Dipartimento di Biologia e Patologia Cellulare e Molecolare, Facoltà di Medicina e Chirurgia di Napoli, Università degli Studi di Napoli 'Federico II'; Email: afusco@napoli.com)
\end{abstract}

\begin{abstract}
Carcinoma of the thyroid gland is an uncommon cancer, but one of the most frequent malignancies of the endocrine system. Most thyroid cancers are derived from the follicular cells. Follicular carcinoma is considered more malignant than papillary thyroid carcinoma (PTC), and anaplastic thyroid cancer (ATC) is one of the most lethal human cancers. Even though several genetic lesions have been already described in human thyroid cancer, particularly in the papillary histotype, the mechanisms underlying the development of these neoplasias are still far from being completely elucidated. Some years ago, several studies were undertaken to analyze the expression of microRNAs (miRNAs or miRs) in thyroid carcinoma to evaluate a possible role of their deregulation in the process of carcinogenesis. These studies showed an aberrant microRNA expression profile that distinguishes unequivocally among PTC, ATC, and normal thyroid tissue. Here, other than summarizing the current findings on microRNA expression in human thyroid carcinomas, we discuss the mechanisms by which microRNA deregulation may play a role in thyroid carcinogenesis, and the possible use of microRNA knowledge in the diagnosis and therapy of thyroid neoplasms.
\end{abstract}

Endocrine-Related Cancer (2010) 17 F91-F104

\section{Introduction}

The thyroid gland is composed of two distinct hormone-producing cell types: follicular cells and parafollicular C-cells. Follicular cells, present in the monolayer epithelium, are responsible for iodine uptake and thyroid hormone synthesis. C-cells are intrafollicular or parafollicular cells that are responsible for the production of the calcium-regulating hormone calcitonin. The majority of the thyroid tumors (more than 95\%) are derived from the follicular cells,

This paper is one of 6 papers that form part of a special Focus Section on microRNAs. The Guest Editors for this section were Professor Alfredo Fusco, Naples, Italy, and Professor Carlo M Croce, Columbus, OH, USA; they were not involved in the handling of this paper, on which they are listed as an author. while a minority (3\%), called medullary thyroid carcinomas, are C-cell-derived carcinomas (Carcangiu et al. 1984, LiVolsi \& Asa 1994, DeLellis et al. 2004, Kondo et al. 2006).

Thyroid tumors are of two types: benign and malignant. Benign tumors are principally represented by adenomas, while malignant tumors are, in most cases, carcinomas. Thyroid carcinomas are one of the most common malignancies of the endocrine system, with $\sim 37000$ new cases diagnosed in the United States in 2008 (Jemal et al. 2008). Follicular cell-derived carcinomas are commonly divided into well-differentiated thyroid carcinoma (WDTC), poorly differentiated thyroid carcinoma (PDTC), and undifferentiated types depending on various histological and clinical factors (Carcangiu et al. 1984, LiVolsi \& Asa 1994, 
DeLellis et al. 2004, Kondo et al. 2006). WDTCs include papillary thyroid carcinoma (PTC) and follicular thyroid carcinoma (FTC) types.

PTCs are characterized by classical papillary architecture and cells with typical nuclear alterations (ground-glass nuclei; DeLellis et al. 2004). Very often, PTCs are multifocal and tend to metastasize to the regional lymph nodes. FTC is a quite uncommon tumor, accounting for about $10 \%$ of all thyroid carcinomas. It may be of conventional or oncocytic (Hurthle cell) type (DeLellis et al. 2004). FTC is well differentiated, usually unifocal, encapsulated, with a tendency to metastasize via the vascular system to the bones and lungs. It is likely that FTCs can develop from pre-existing benign follicular adenomas (FTAs) or by directly bypassing the stage of adenoma. The differential diagnosis between the FTCs and the, far more frequent, FTAs is difficult, thus making FTCs of noticeable clinical importance.

Anaplastic thyroid cancers (ATCs) are very rare tumors estimated to comprise about $2-5 \%$ of thyroid malignancies. ATCs are highly undifferentiated, extremely aggressive and insensitive to conventional radiotherapy and chemotherapy (Ain 1999, Yau et al. 2008). ATCs may derive from the progression of pre-existing PTCs and FTCs. Such a hypothesis is validated by the presence, in some patients, of undifferentiated (anaplastic) areas that co-exist with more differentiated areas of papillary or follicular type (Ain 1999). As far as PDTCs are concerned, their morphology and behavior is intermediate between WDTC and undifferentiated thyroid carcinomas (Carcangiu et al. 1984, DeLellis et al. 2004).

Radiation exposure is the major risk factor for PTCs. Indeed, PTC incidence was verified among the atomic bomb survivors of Hiroshima and Nagasaki (Williams 2002). In the 1950s, patients treated with irradiation in the head and neck region for the cure of thymic hyperplasia or mycotic infections developed higher susceptibility to PTCs. Furthermore, after the nuclear reaction accident of Chernobyl in April 1986, children, mostly in Belarus and Ukraine, exhibited an increased PTC incidence (up to 100 times). It was also found that post-Chernobyl PTCs, often presenting a particular type of histology with dense cell structure (solid PTC variant), were more aggressive than those found in regions not exposed to radiations (Williams 2002).

Endemic goiter due to the lack of iodine represents one of the major risk factors for FTC development since the incidence of FTCs is higher in areas of iodine deficiency than in those with a diet rich in iodine (Harach et al. 2002, DeLellis et al. 2004).
Genetic factors other than the environmental ones may as well play a role in thyroid carcinogenesis. An idiopathic form of familial nonmedullary thyroid carcinoma accounts for 3.5-6.2\% of thyroid cancers (Lupoli et al. 1999). Familial thyroid cancers associated with tumor syndromes caused by known germline mutations include familial polyposis coli, Cowden disease, and Werner syndrome (Lindor \& Greene 1998). It has recently been shown that an important role to the onset of familial PTCs and FTCs can be attributed to the common variants located in the loci $13 q 22.33$ and 14q13.3. Forkhead box E1 (also known as thyroid transcription factor 2, TTF2) is the gene nearest to the 9q22.33 locus, and NK2 homeobox 1 (also known as TTF1) is among the genes located at the 14q13.3 locus. These variants account for an increased risk of both PTCs and FTCs. Approximately $3.7 \%$ of individuals are homozygous for both variants, and their estimated risk of thyroid cancer is 5.7-fold greater than that of noncarriers (Gudmundsson et al. 2009).

Several oncogenes have been involved in thyroid carcinoma development (Table 1). In PTCs, nonoverlapping mutations of genes involved in the activation pathway of mitogen-activated protein kinase (MAPK), such as RET, TRK, RAS, and BRAF, have been found in about $70 \%$ of the cases (Kimura et al. 2003, Soares et al. 2003, Frattini et al. 2004). Indeed, a fraction of about $30 \%$ of PTCs present a typical gene alteration consisting in the rearrangement of RET proto-oncogene (Santoro et al. 2004; Table 1). At least ten different types of RET/PTC rearrangements have been reported (Nikiforov 2002). The RET/PTC rearrangements consist in the fusion of tyrosine kinase (TK) domain of RET with other genes that provide to the chimeric gene the promoter and the $5^{\prime}$ coding region. RET/PTC1 and RET/PTC3 are the most frequent isoforms found in PTCs. RET/PTC1 was generated by the fusion of the RET TK domain with the $5^{\prime}$ terminal region of a new gene that was denominated H4 (now CCDC6; Grieco et al. 1990), whereas in RET/PTC3, the TK domain of RET is fused to the RFG gene (also designated Ele1/ARA70/Ncoa4; Santoro et al. 1994).

The isolation of RET/PTC genes together with the existence, in fewer cases, of analogous rearrangements of the TRK gene, which encodes another protein with a TK function, confirms that TKs play an important role in PTC formation. Under normal conditions, TRK encodes a receptor for the nerve growth factor. TRK rearrangements and fusion genes very similar to RET/PTC rearrangements have been described in about 10\% of PTC cases (Pierotti et al. 1995; Table 1). 


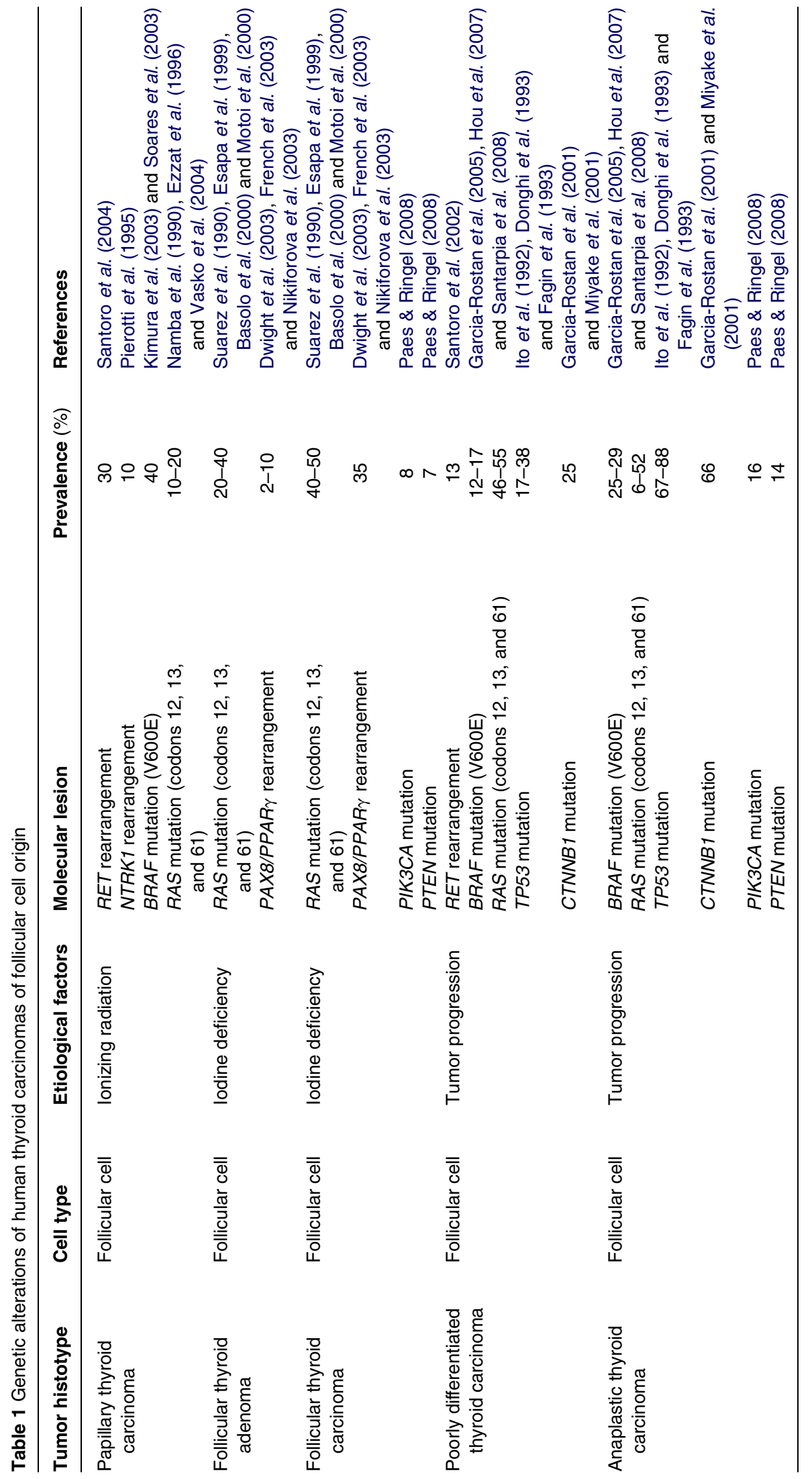


In most PTC cases, a specific point mutation of $B R A F$ is found. The BRAF T1799A mutation is the most common genetic change in PTCs and occurs in about $40 \%$ of PTCs (Table 1; Kimura et al. 2003, Soares et al. 2003). As in melanomas, the most common $B R A F$ mutation results from $\mathrm{T}>\mathrm{A}$ transversions at position 1799 , resulting in a valine $>$ glutamate substitution at residue 600 (V600E) that destabilizes the inactive conformation of the RAF kinase (Dhillon \& Kolch 2004).

In PTCs, BRAF mutation and RET/PTC rearrangements are mutually exclusive and cannot be found simultaneously in the same patients, yet they are not completely equivalent, since it has been shown that PTCs positive for $B R A F$ are more aggressive than those positive for RET/PTC (Kimura et al. 2003, Soares et al. 2003).

It has recently been demonstrated that some types of PTCs developed after the Chernobyl nuclear accident present a different $B R A F$ alteration since they harbored a rearrangement similar to the RET/PTC rearrangements, which results in the fusion between $B R A F$ kinase domain and the $A K A P 9$ gene and is caused by a paracentric inversion of the long arm of chromosome 7 (Ciampi et al. 2005).

Mutations of the $R A S$ genes ( $K-R A S, H-R A S$, and $N$-RAS), present in codons 12, 13, and 61 (Table 1), are observed in 10-20\% of PTCs (Namba et al. 1990, Ezzat et al. 1996, Vasko et al. 2004; Table 1). RAS gene mutations represent early molecular lesions since they are also frequently found in FTAs which are considered FTC precursors. In fact, $R A S$ mutations are observed in $40-50 \%$ of conventional FTCs and in 20-40\% of FTAs (Suarez et al. 1990, Esapa et al. 1999, Basolo et al. 2000, Motoi et al. 2000). Another FTC group presents a specific chromosomal translocation $\mathrm{t}(2 ; 3)(\mathrm{q} 13 ; \mathrm{p} 25)$, and results in the fusion of two nuclear proteins with transcriptional activity: $P A X 8$ and peroxisome proliferator-activated receptor $\gamma$ (PPAR $\gamma$; Kroll et al. 2000; Table 1). PAX8/PPAR $\gamma$ rearrangement occurs in $\sim 35 \%$ of conventional FTCs, and with a lower prevalence in oncocytic carcinomas also (Dwight et al. 2003, French et al. 2003, Nikiforova et al. 2003).

PDTCs and ATCs can originate from WDTCs and, in particular, from PTCs. Therefore, mutations that occur in the early stages of WDTCs are also observed in PDTCs and ATCs: in PDTCs, RET rearrangements (13\%) as well as RAS (46-55\%) and BRAF (12-17\%) mutations are observed, while in ATCs, only mutations of RAS (6-52\%) and BRAF (25-29\%) are reported (Santoro et al. 2002, Garcia-Rostan et al. 2005, Hou et al. 2007, Santarpia et al. 2008; Table 1).
Alterations of PIK3CA and PTEN (effectors of phosphoinositide 3-kinase) have also been found in thyroid carcinomas. These alterations are generally observed in the later stages of thyroid carcinogenesis and are more frequent in ATCs (16 and 14\% respectively) than in WDTCs ( 2 and $2 \%$ respectively) or FTCs (8 and 7\% respectively; Paes \& Ringel 2008; Table 1). This is in contrast with mutations of the $M A P K$ effectors that are preferentially associated with the early stages of thyroid carcinogenesis. More recently, an AKT1 oncogene mutation in PDTCs has also been observed (Ricarte-Filho et al. 2009). This mutation is commonly associated with $B R A F$ mutations and does not overlap with PIK3CA mutations in PDTCs (Ricarte-Filho et al. 2009). Impairment of the p53 tumor suppressor gene function represents a usual feature of ATCs with $p 53$ mutations being common both in PDTCs (17-38\%) and in ATCs (67-88\%), but rare or absent (0-9\%) in WDTCs (Ito et al. 1992, Donghi et al. 1993, Fagin et al. 1993; Table 1). Moreover, mutations of CTNNB1 ( $\beta$-catenin) have been found in $25 \%$ of PDTCs and in 66\% of ATCs (Garcia-Rostan et al. 2001, Miyake et al. 2001; Table 1).

MicroRNAs (miRNAs or miRs) constitute a class of small endogenous noncoding RNAs of 19-23 nucleotides that negatively regulate gene expression (Bartel 2004). They are an abundant class of gene regulatory molecules in multicellular organisms and modulate the expression of many protein-coding genes (Bartel 2004). They are transcribed as a huge double-stranded primary transcript (pri-miR) by RNA polymerase II. Subsequently, nuclear enzymes Drosha and Pasha convert this precursor into a double-stranded miR precursor of $\sim 70$ nucleotides (pre-miR), which is next transported into the cytoplasm by a mechanism involving the protein Exportin. Finally, Dicer enzyme processes this precursor into the 22-nucleotide doublestranded miR. This duplex is then unwinded, and the leading strand, one of the two strands, is incorporated into the RISC. miRs incorporated in the RISC are able to bind to the $3^{\prime}$ untranslated region (UTR) of the target mRNAs causing a block of translation or mRNA degradation depending on the level of complementarity (Rhoades et al. 2002, Tang et al. 2003, Ambros 2004, Bartel 2004). Recent studies have clearly demonstrated that they play critical roles in several biologic processes, including differentiation, development, cell growth, and apoptosis, by regulating gene expression through either the inhibition of mRNA translation or the induction of its degradation (Ambros 2004). The analysis of human neoplasias of different tissue origins has shown deregulated miR expression (Calin \& Croce 2006, Volinia et al. 2006). 


\section{miR expression profile in PTCs}

Most studies have focused on the analysis of miR expression profile of PTCs by 'miRNACHIP' microarray revealing the upregulation of a set of seven miRs in PTCs compared with the normal thyroid, including $m i R-221,-222,-146,-21,-155,-181 a$, and $-181 b$ (Table 2). Quantitative RT-PCR on a large panel of PTCs confirmed the upregulation of this set of miRs (He et al. 2005, Pallante et al. 2006, Tetzlaff et al. 2007). The upregulation of $m i R-221,-222$, and $-181 b$, observed in all the cases analyzed, showed a value of fold-change that in some cases was higher than 10 . Moreover, the upregulation of $m i R-221$ in unaffected thyroid tissue in several PTC patients suggests miR induction as a possible early event in carcinogenesis (He et al. 2005). The critical role of the upregulation of these miRs in thyroid cell transformation was supported by the dysregulation of $m i R-221,-222$, and $-181 b$ in the experimental models of thyroid carcinogenesis. Indeed, $m i R-221,-222$, and $-181 b$ were not found in the normal thyroid cells $\mathrm{PC} \mathrm{Cl} 3$, whereas they were highly expressed in the same cells transformed by v-ras-Ha, v-ras-Ki, v-raf, RET/PTC1, RET/PTC3, E1-Abl, E1a-v-raf, middle $\mathrm{T}$ of Polyomavirus, and v-mos. These miRs also revealed an elevated expression in the carcinomas of papillary histotype occurring in transgenic animal lines expressing TRK, RET/PTC3 and HPV E7 under the transcriptional control of the thyroglobulin $(\mathrm{Tg})$ promoter, while they had low expression levels in normal mouse thyroid tissues (Pallante et al. 2006).

Since several genetic lesions have been detected in PTCs, the miR expression profile was analyzed in PTCs already selected for genetic mutations. This study revealed a strong correlation between the miR expression and the mutational status. MiR-187 was expressed at high levels in PTCs harboring RET/PTC rearrangements, whereas $m i R-221$ and -222 were found at the highest level in $B R A F$ - and $R A S$-positive PTCs and those with no known mutations. RAS-positive PTCs expressed the highest amount of miR-146. Essentially, it can be stated that $B R A F$ - and $R E T / P T C$-positive tumors segregated into separate clusters, while $R A S$-positive tumors did not form separate clusters (Nikiforova et al. 2008). However, PTCs keep some changes in the expression profile independently from the mutational status. The mechanism by which these miRs are upregulated in PTCs is still under investigation. In all the papers reported so far, no gene amplification or changes in the methylation status have been found, making us assume that other epigenetic mechanisms may be responsible for miR overexpression (Pallante et al. 2006).

It is also of note that even though PTCs include different subgroups such as classical PTCs, Hurthle cell variant of PTCs, and tall cell, follicular variant of PTCs, a clear correlation between miR profile and histological subtypes has not been evidenced so far.

Table 2 miRs aberrantly expressed in human thyroid carcinomas of follicular cell origin

\begin{tabular}{|c|c|c|c|c|}
\hline $\begin{array}{l}\text { Tumor } \\
\text { histotype }\end{array}$ & & miR deregulation & Up/down & References \\
\hline \multirow[t]{8}{*}{ PTC } & & $146,221,222,21,220,181 a, 155$ & Up & He et al. (2005) \\
\hline & & $26 a-1,345,138,219$ & Down & He et al. (2005) \\
\hline & & $222,221,181 b, 220,213$ & Up & Pallante et al. (2006) \\
\hline & & $187,221,222,146 b, 155,122 a, 31,205,224$ & Up & Nikiforova et al. (2008) \\
\hline & & $1,191,486,451$ & Down & Leone et al. ${ }^{\mathrm{a}}$ \\
\hline & & $146 b, 221,222$ & Up & Chen et al. (2008) \\
\hline & & $221,222,21,31,172,34 a, 213,181 b, 223,224$ & Up & Tetzlaff et al. (2007) \\
\hline & & $218,300,292,345,30 c$ & Down & Tetzlaff et al. (2007) \\
\hline \multirow[t]{2}{*}{ FTA } & Conventional type & $339,224,205,210,190,328,342$ & Up & Nikiforova et al. (2008) \\
\hline & Oncocytic type & $31,339,183,221,224,203$ & Up & Nikiforova et al. (2008) \\
\hline \multirow[t]{3}{*}{ FTC } & Conventional type & $187,224,155,222,221,146 b$ & Up & Nikiforova et al. (2008) \\
\hline & Oncocytic type & $187,221,339,183,222,197$ & Up & Nikiforova et al. (2008) \\
\hline & & $192,197,328,346$ & Up & Weber et al. (2006) \\
\hline PDTC & & $187,221,129,222,146 b, 339,183$ & Up & Nikiforova et al. (2008) \\
\hline \multirow[t]{5}{*}{ ATC } & & $30 d, 125 b, 26 a, 30 a-5 p$ & Down & Visone et al. (2007b) \\
\hline & & $302 c, 205,137,187,214,155,224,222,221$ & Up & Nikiforova et al. (2008) \\
\hline & & $21,146 b, 221,222$ & Up & Mitomo et al. (2008) \\
\hline & & $26 a, 138,219,345$ & Down & Mitomo et al. (2008) \\
\hline & & $17-5 p, 17-3 p, 18 a, 19 a, 20 a, 19 b, 92-1,106 a, 106 b$ & Up & Takakura et al. (2008) \\
\hline
\end{tabular}

'Leone V, D'Angelo D \& Fusco A, unpublished observation. 
The diagnostic utility of $\mathrm{miR}$ expression was explored in order to translate the analysis of these molecules in clinical applications by analyzing the expression of the miRs overexpressed in fine-needle aspiration (FNA) specimens of PTCs. Pallante et al. (2006) found $m i R-221,-222$, and $-181 b$ overexpression in seven of eight lesions corresponding to thyroid nodules, which were diagnosed as PTC after surgery. Chen et al. (2008) also demonstrated the possible use of $m i R-146 b$ as a marker for diagnosing PTCs in both FNA and surgical specimens. In another study, the expression of a set of seven miRs ( $m i R-187,-221,-222$, $-224,-146 b,-155$, and -197) was analyzed in FNA specimens of thyroid carcinomas and of hyperplastic nodules (Nikiforova et al. 2008). The evaluation of these miRs was very useful in differentiating thyroid cancer from hyperplastic nodules. In fact, the supervised prediction analysis by linear discriminant analysis failed to distinguish only one of 41 malignant tumors and hyperplastic nodules (Nikiforova et al. 2008). These results indicate the evaluation of these miRs as a potential application for the diagnosis of human thyroid neoplasias.

\section{Role of the miR-221/222 cluster in thyroid carcinogenesis}

$M i R-221$ and -222 are the most consistently upregulated miRs in PTCs. They are very similar in sequence, clustered on chromosome $\mathrm{X}$, and are likely transcribed as polycistrons (Ciafrè et al. 2005). Functional studies were performed to understand their role in thyroid carcinogenesis. Using a colony assay, it was demonstrated that the $m i R-221$ and -222 overexpression on thyroid carcinoma cell lines increased the number of colonies $(>2$-fold) in comparison to the same cells transfected with an empty vector. Opposite results were obtained when thyroid carcinoma cell lines were treated with the $m i R-221$ and -222 antisense oligonucleotides (Pallante et al. 2006). These results suggest that $m i R-221$ and -222 overexpression plays a significant role in thyroid carcinoma cell proliferation.

Several targets for the $m i R-221 / 222$ cluster have been identified. One of these is $c$-KIT (Felli et al. 2005), also called $C D 117$, a cytokine receptor for the stem cell factor expressed on the surface of hematopoietic stem cells as well as in other cell types. In most PTCs, the loss of $c$-KIT transcript and c-KIT protein has been described (Natali et al. 1995); however, its role in thyroid carcinogenesis is still unknown.

More recently, the $C D K N 1 B\left(p 27^{K i p 1}\right)$ gene was identified as a target of $m i R-221$ and -222 (Galardi et al. 2007, Visone et al. 2007a). p27 ${ }^{\mathrm{Kip} 1}$, member of
Cip/Kip family which also includes $\mathrm{p} 21^{\mathrm{Cip} 1}$ and p5 $7^{\text {Kip2 }}$, represents a very important regulator of cell cycle (Gu et al. 1993, Polyak et al. 1994, Chen et al. 1995). Cip/Kip family together with INK4 proteins (p16 ${ }^{\text {INK4a }}, \mathrm{p} 15^{\text {INK4b }}, \mathrm{p} 18^{\text {INK4c }}$, and p19 ${ }^{\text {INK4d }}$ ) makes part of the cyclin-dependent kinase (CDK) inhibitors (CDKI; Serrano et al. 1993, Guan et al. 1994, Hannon et al. 1994, Hirai et al. 1995). These proteins contrast the activities of CDKs which are involved in the regulation of the mitogen-dependent progression through gap phase 1 (G1 phase) and initiation of DNA synthesis (S phase) during the mammalian cell division cycle (Kaldis 2007). Reduced $\mathrm{p} 27^{\mathrm{Kip} 1}$ protein levels were found in a high number of human thyroid malignancies in the absence of significant changes in p27 mRNA levels (Baldassarre et al. 1999). When transfected into PTC cell line, $m i R-221$ and/or -222 decreased $\mathrm{p} 27^{\mathrm{Kip} 1}$ protein levels, which were increased by the treatment with their inhibitors. Interestingly, no significant changes in the $p 27^{\mathrm{Kip} 1}$ mRNA levels were found in the cells transfected with either $m i R-221$ and -222 or their inhibitors, excluding their role in $p 27^{\text {Kip } 1}$ mRNA degradation. The regulation of $\mathrm{p} 27$ by $m i R-221$ and -222 was direct, as they negatively regulated the expression of the $3^{\prime}$ UTR-based reporter construct from the $p 27^{\mathrm{Kip} 1}$ gene, and was dependent on two target sites in this mRNA region (Visone et al. 2007a). Consistently with the key role of $\mathrm{p} 27^{\mathrm{Kip} 1}$ in the cell cycle, particularly in the cell growth arrest at the G1/S transition, the enforced expression of $m i R-221$ and -222 stimulates thyroid carcinoma cells to overcome the G1/S block. Therefore, the role of the $m i R-221 / 222$ cluster overexpression may account for the reduced p $27^{\text {Kip1 }}$ expression in several tumors. Consistently, a significant inverse correlation between $\mathrm{p} 27^{\mathrm{Kip} 1}$ protein levels and $m i R-221$ and -222 expression was found in PTCs (Visone et al. 2007a). Other studies have shown that $m i R-221$ can also target $C D K N 1 C / \mathrm{p} 57$ that has a critical role in the cell-cycle control (Fornari et al. 2008). Therefore, the upregulation of $m i R-221 / 222$ significantly modifies the cell cycle of thyroid cells, and when associated with a genetic lesion involving the MAPK pathway, could lead to the malignant phenotype.

MiR-221 and -222 are also able to impair tumor necrosis factor (TNF)-related apoptosis inducing ligand (TRAIL)-dependent apoptosis by inhibiting the expression of key functional proteins (Garofalo et al. 2008). Recent results indicate that $m i R$ - 222 plays an important role in cancer cell invasion. Indeed, ectopic transfection of $m i R-222$ reduced the expression of matrix metalloproteinase $1(M M P 1)$ and manganese superoxide dismutase 2 (SOD2) in oral tongue 
squamous cell carcinoma cell line. Interestingly, SOD2 knockdown by siRNA led to the downregulation of MMP1 expression. Consequently, $m i R-222$ would regulate the $M M P 1$ expression through both direct cis-regulatory mechanism (targeting MMPl mRNA) and indirect trans-regulatory mechanism (indirect controlling of $M M P 1$ gene expression by targeting SOD2; Liu et al. 2009).

In conclusion, the overexpression of $m i R-221$ and -222 targets critical genes, making their overexpression a crucial factor in the process of thyroid oncogenesis.

\section{MiR-146 in thyroid cancer}

MiR-146 represents one of the most upregulated miRs in PTCs. It identifies two different miRs that differ only for two nucleotides: $m i R-146 a$ (on chromosome 5q33) and $-146 b$ (on chromosome 10q24). Additional forms of mature miRs can originate from the passenger strand of miR-146b (Jazdzewski et al. 2009).

Both miR-146 isoforms are overexpressed in PTC samples, with $m i R-146 b$ showing a higher expression than miR-146a in several specimens (He et al. 2005, Jazdzewski et al. 2008). These two miRs are differently regulated: lipopolysaccharide is able to strongly induce $m i R-146 a$, but not $m i R-146 b$, and the promyelocytic leukemia zinc finger protein transcription factor is able to downregulate only $m i R-146 a$ (Labbaye et al. 2008). Moreover, recent data demonstrate that the control of miR-146a and $-146 b$ expression differs depending on cell type and environment (Hurst et al. 2009).

It has been reported that miR-146a and $-146 b$ can interact with a domain in the exon 18 region of the $c$-KIT mRNA. Intriguingly, there is a single-nucleotide polymorphism (SNP; 2607G $>$ C) located in the crucial region of the $c$-KIT mRNA pairing with miR-146. This event could lead to changes in the duplex conformation between miR and mRNA and result in hybridization with a different region, modulating the expression of the target gene in a different manner (He et al. 2005).

Since miR-146a and $-146 b$ show high sequence homology, they share many predicted targets, but each of them has specific targets. MiR-146 suppresses nuclear factor- $\kappa \mathrm{B}(N F-\kappa \mathrm{B})$ activity that regulates its expression (Taganov et al. 2006, Bhaumik et al. 2008). Moreover, the breast cancer metastasis suppressor 1 upregulates miR-146a and $-146 b$, which suppress breast cancer metastasis since they are able to inhibit migration and invasion likely reducing the signaling through the $N F-\kappa B$ pathway (Hurst et al. 2009).
This appears to be a rather interesting novel principle of local feedback regulatory circuits.

Because the role of $N F-\kappa B$ in thyroid carcinogenesis has been clearly well established already (Visconti et al. 1997, Pacifico et al. 2004, McCall et al. 2007), we can assume that the miR-146 overexpression might contribute to the development of PTCs.

Other targets of miR-146 are interleukin-1 (IL-1) receptor-associated kinase 1 (IRAK1; Taganov et al. 2006, Bhaumik et al. 2008), TNF receptor-associated factor 6 (TRAF6; Taganov et al. 2006, Bhaumik et al. 2008), IL-8, (Bhaumik et al. 2008), IL-6, (Bhaumik et al. 2008), C-X-C chemokine receptor type 4 (CXCR4; Labbaye et al. 2008), MMP9 (Bhaumik et al. 2008), and epidermal growth factor receptor (Griffiths-Jones et al. 2008, Hurst et al. 2009). Recently, a role for $m i R-146$ has been proposed in the control of toll-like receptor and cytokine signaling through a negative feedback regulation loop involving downregulation of IRAK1 and TRAF6 protein levels (Taganov et al. 2006, 2007). In the pre-miR-146a, there is a common $\mathrm{G} / \mathrm{C}$ polymorphism designated rs2910164 (Jazdzewski et al. 2008). Because of this SNP in its sequence, $m i R-146 a$ gene generates two transcript isoforms: $m i R-146 a-G$ and $m i R-146 a-C$. Therefore, while two mature miRs originate from GG and CC homozygotes (miR-146a and miR-146a-G or $146 a-C$ respectively from the passenger strand), three mature miRs arise from GC heterozygotes $(m i R-146 a$ and both miR-146a-G and -146a-C; Jazdzewski et al. 2009). The G/C polymorphism also affects the final production of mature miR-146a by reducing the stability of the pri-miR, decreasing the efficiency of processing the pri-miR into pre-miR, or the pre-miR into mature miR (Jazdzewski et al. 2008). The G/C polymorphism shows a marked difference in genotype distribution and seems to affect the predisposition to PTCs, and in fact, an increased risk to develop PTCs is associated with the GC heterozygous status (Jazdzewski et al. 2008). Moreover, 4.7\% of analyzed tumors showed somatic mutations of the SNP from both homozygous states to heterozygosity (Jazdzewski et al. 2008). This is a rare phenomenon (overdominance) in which heterozygosity is a genetic risk rather than homozygosity (Jazdzewski et al. 2008, 2009).

Since the G/C polymorphism is located in the region of complementarity between the miR-146a and the target mRNAs, different mechanisms might be envisaged to explain the predisposition to PTCs by the GC state of the SNP: 
a) The different isoforms of $m i R-146 a$ could have different targets or act with different efficiency on them. Indeed, miR-146a- $G$ reduces the expression of IRAKI and TRAF6 more efficiently than miR-146a-C (Jazdzewski et al. 2008).

b) In the heterozygous state, there are three sets of miRs and therefore a higher number of target genes.

\section{miRs downregulated in PTCs}

Our group, by analyzing more PTC samples, has recently found other miRs deregulated in PTCs (Table 2), among which are miR-1, -191, -486, and -451. These miRs showed lower expression levels in most of the PTCs analyzed compared to normal thyroid tissue. We have found that $m i R-1$ is able to target CXCR4 (V Leone, submitted for publication). This protein, also called fusin, is an $\alpha$-chemokine receptor specific for stromal cell-derived factor-1 (also called CXCL12), a molecule endowed with potent chemotactic activity for lymphocytes (Bleul et al. 1996). CXCR4 is frequently overexpressed in PTCs and plays a major role in the mechanism of lymph node metastasis from primary tumor (Castellone et al. 2004). Therefore, the downregulation of $m i R-1$ may have a critical role in the tropism of PTC cells to the local lymph nodes. The tumor suppressor role of $m i R-1$ in thyroid carcinogenesis is further supported by its ability to reverse the tumorigenic properties (such as growth, motility, migration, clonogenic survival, and tumor formation in athymic mice) of lung cancer cells (Nasser et al. 2008).

\section{miR expression in FTCs}

Even though most of the studies conducted so far on miR expression in thyroid cancer have focused on PTCs, recently several papers have reported miR deregulation in FTCs also. It has been shown by Nikiforova et al. (2008) that a different signature is associated with follicular adenoma and carcinoma both in conventional variants and in oncocytic ones. The most highly upregulated miRs in conventional FTCs were $m i R-187,-224,-155,-222$, and -221 , and those in oncocytic variants were $m i R-187,-221,-339,-183$, -222 , and -197 , whereas the most highly upregulated miRs in conventional FTAs were $m i R-339,-224,-205$, $-210,-190,-328$, and -342 , and those in oncocytic variants were $m i R-31,-339,-183,-221,-224$ and -203 (Nikiforova et al. 2008). Interestingly, the upregulation of these miRs was not observed in hyperplastic nodules. In another study, Weber et al. (2006) identified four miRs differentially expressed between FTCs and FTAs (miR-192, -197, -328, and -346). Moreover, in vitro functional analyses showed that the overexpression of $m i R-197$ and -346 induced marked cell proliferation in HEK293T cells, while their inhibition caused growth arrest in human thyroid carcinoma follicular cells (FTC133; Weber et al. 2006). They also confirmed the regulation of three target genes by miR-197 (ACVRl and TSPAN3) and -346 (EFEMP2). EFEMP2 seems to have tumor suppressor functions (Gallagher et al. 2001, Argraves et al. 2003), whereas ACVRI is involved in the control of cell growth (Schulte et al. 2001). TSPAN3 belongs to the tetraspan superfamily, whose members have been shown to be inversely correlated with the acquisition of metastatic potential in melanoma (Schulte et al. 2000, Boucheix et al. 2001).

\section{miR expression in anaplastic thyroid carcinomas}

As far as ATCs are concerned, a significant downregulation of $m i R-30 d,-125 b,-26 a$, and $-30 a-5 p$ has been described (Table 2; Visone et al. 2007b). The possible role of these miRs in the generation of ATCs seems to be validated by the mouse models of carcinogenesis. Indeed, they were downregulated in ATCs developing in transgenic animal mice expressing SV40 large $T$ oncogene under the transcriptional control of the the Tg promoter (Ledent et al. 1991). A role of $m i R-30$ and $-125 b$ downregulation in thyroid cancer progression seems to be supported by recent results showing a decreased expression of these miRs in other malignant neoplasias, such as prostate cancer for both the miRs (Ozen et al. 2008) and oral squamous cell carcinoma for $m i R-125 b$ (Henson et al. 2009). Recent results report a role of $m i R-30 a$ in regulating Beclin 1, the mammalian homologue of yeast Atg6, a key autophagy-promoting gene that plays a critical role in the regulation of cell death and survival of various cell types. Consistently, treatment of tumor cells with miR-30a results in the decreased autophagic activity (Zhu et al. 2009). Among the potential targets of $m i R-125 b$, there is the sel-1 suppressor of lin-12-like (SEL1L) protein, upregulated in prostate carcinomas, which may play a role in breast and pancreatic cancer aggressiveness (Biunno et al. 2006). Just recently, the tumor suppressor role of the $m i R-26 a$ also appears to be validated by the finding of a reduced expression of this miR in human liver carcinomas in comparison to normal liver cells. Moreover, it has been demonstrated that the enforced expression of $m i R-26 a$ in 
liver cancer cells induces cell-cycle arrest associated with direct targeting of cyclins D2 and E2, and systemic administration of this $\mathrm{miR}$ in a mouse model of human hepatic carcinoma, using adenoassociated virus, results in the inhibition of cancer cell proliferation, induction of tumor-specific apoptosis, and dramatic protection from disease progression (Kota et al. 2009). More recently, Schwertheim et al. (2009) confirmed the downregulation of these miRs and let-7c in a different panel of ATC samples.

A recent study revealed an upregulation of several miRs in ATCs (Table 2). Interestingly, these miRs were found to be overexpressed also in WDTCs deriving from follicular cells, and some of them such as $m i R-302 c,-205$, and -137 resulted overexpressed in comparison to hyperplastic nodules (Nikiforova et al. 2008).

Another study (Mitomo et al. 2008) revealed that miR-21, -146b, -221, and -222 were overexpressed in ATCs (Table 2). Among the downregulated miRs were found $m i R-26 a,-138,-219$, and -345 . A potential target of $m i R-138$ is the human telomerase reverse transcriptase (hTERT) whose overexpression has been associated with dedifferentiation, tumor stage, and increased metastatic and invasive phenotypes (Ito et al. 2005, Mitomo et al. 2008). These results suggest that loss of $m i R-138$ expression may partially contribute to the gain of hTERT protein expression in ATC cells (Mitomo et al. 2008).

It has been recently reported by Takakura et al. (2008) that the miR-17-92 cluster of seven miRs (miR-17-5p, -17-3p, -18a, -19a, -20a, -19b, and -92-1) as well as $m i R-106 a$ and $-106 b$ was overexpressed in ATC cell lines. MiR-17-3p and -17-5p resulted overexpressed also in human ATC samples compared to normal tissue. The inhibition of $m i R-17-3 p,-17-5 p$, and $-19 a$ resulted in a reduced cell growth, thus suggesting an oncogenic potential of these miRs. In this study, retinoblastoma protein $(R B I)$ and $P T E N$, predicted to be putative targets in previous studies (Griffiths-Jones et al. 2006), are now confirmed to be targets of $m i R-17-5 p$ and $-19 a$ (Takakura et al. 2008).

$M i R-17$ family of miR has been demonstrated to modulate fibroblast growth factor 10 (FGF10) fibroblast growth factor receptor $2 b$ (FGFR2b) downstream signaling by specifically targeting the signal transducer and activator of transcription 3 (STAT3) and the MAPK14, hence regulating E-cadherin expression, which in turn modulates epithelial bud morphogenesis in response to FGF10 signaling
(Carraro et al. 2009). Therefore, the overexpression of $m i R-17$ family members might contribute to the development of a significant number of ATC cases.

\section{Conclusions and perspectives}

Several studies have shown deregulation of miR expression in human thyroid carcinomas, and functional studies support a critical role of miRs in thyroid carcinoma development.

The generation of transgenic mice overexpressing these miRs under the control of a thyroid-specific promoter (i.e. $\mathrm{Tg}$ ), and also their crossing with transgenic mice expressing the most frequently activated oncogenes (RET/PTC 3, TRK-T1, and $N-R A S)$ in thyroid carcinomas, could help clarify their role in thyroid carcinogenesis. The deregulated expression of these miRs together with their biological role suggests a correlation with diagnosis, prognosis, and therapeutic approaches. However, even though two studies show that the evaluation of the expression of a set of miRs can allow the distinction between thyroid cancer and hyperplastic nodules, a miR signature that could clearly distinguish benign FTAs from FTCs - the major challenge in the preoperative diagnosis - is not available at the moment.

Hopefully, taking advantage of the miRs identified recently, further studies may be helpful in achieving this important aim.

Inhibition of miRs such as $m i R-221,-222$, and -146, with 'antagomirs' or 'locked nucleic acid-modified anti-miRs' (LNA-antimiRs; to be tested in animal models of thyroid carcinogenesis), is an attractive direction for therapy. Restoration of downregulated miRs as well could be a tool to improve patient care and response to treatment. Just recently, Kota et al. (2009) have reported that restoration of the miR-26 (a miR constantly downregulated in ATCs) expression in hepatocellular carcinoma cells using an adenoassociated virus results in the inhibition of cancer cell proliferation, induction of tumor-specific apoptosis, and remarkable protection from disease progression. This result suggests a possible use of $m i R-26 a$ restoration in ATC that is well known to be refractory to any conventional radiotherapy and chemotherapy. Moreover, the possibility to antagonize the liverexpressed miR-122 in nonhuman primates by the simple systemic delivery of LNA-antimiRs (Elmén et al. 2008) makes the utilization of systemically delivered LNA-antimiRs for the therapy of thyroid and nonthyroid carcinomas not futuristic. 


\section{Declaration of interest}

The authors declare that there is no conflict of interest that could be perceived as prejudicing the impartiality of the research reported.

\section{Funding}

This work was supported by grants from the Associazione Italiana per la Ricerca sul Cancro (AIRC) and from NOGEC-Naples Oncogenomic Center.

\section{Acknowledgements}

We thank the Associazione Partenopea per le Ricerche Oncologiche (APRO) for its support. We are grateful to Konstantina Vergadou (Scientific Communication) for editing the text.

\section{References}

Ain KB 1999 Anaplastic thyroid carcinoma: a therapeutic challenge. Seminars in Surgical Oncology 16 64-69.

Ambros V 2004 The functions of animal microRNAs. Nature 431 350-355.

Argraves WS, Greene LM, Cooley MA \& Gallagher WM 2003 Fibulins: physiological and disease perspectives. EMBO Reports 4 1127-1131.

Baldassarre G, Belletti B, Bruni P, Boccia A, Trapasso F, Pentimalli F, Barone MV, Chiappetta G, Vento MT, Spiezia S et al. 1999 Overexpressed cyclin D3 contributes to retaining the growth inhibitor p27 in the cytoplasm of thyroid tumor cells. Journal of Clinical Investigation 104 $865-874$.

Bartel DP 2004 MicroRNAs: genomics, biogenesis, mechanism, and function. Cell 116 281-297.

Basolo F, Pisaturo F, Pollina LE, Fontanini G, Elisei R, Molinaro E, Iacconi P, Miccoli P \& Pacini F 2000 N-ras mutation in poorly differentiated thyroid carcinomas: correlation with bone metastases and inverse correlation to thyroglobulin expression. Thyroid 10 19-23.

Bhaumik D, Scott GK, Schokrpur S, Patil CK, Campisi J \& Benz CC 2008 Expression of microRNA-146 suppresses NF-kappaB activity with reduction of metastatic potential in breast cancer cells. Oncogene 27 5643-5647.

Biunno I, Cattaneo M, Orlandi R, Canton C, Biagiotti L, Ferrero S, Barberis M, Pupa SM, Scarpa A \& Ménard S 2006 SEL1L a multifaceted protein playing a role in tumor progression. Journal of Cellular Physiology 208 23-38.

Bleul CC, Fuhlbrigge RC, Casasnovas JM, Aiuti A \& Springer TA 1996 A highly efficacious lymphocyte chemoattractant, stromal cell-derived factor 1 (SDF-1). Journal of Experimental Medicine 184 1101-1109.
Boucheix C, Duc GH, Jasmin C \& Rubinstein E 2001 Tetraspanins and malignancy. Expert Reviews in Molecular Medicine 2001 1-17.

Calin GA \& Croce CM 2006 MicroRNA signatures in human cancers. Nature Reviews. Cancer 6 857-866.

Carcangiu ML, Zampi G \& Rosai J 1984 Poorly differentiated ("insular") thyroid carcinoma. A reinterpretation of Langhans' "wuchernde Struma". American Journal of Surgical Pathology 8 655-668.

Carraro G, El-Hashash A, Guidolin D, Tiozzo C, Turcatel G, Young BM, De Langhe SP, Bellusci S, Shi W, Parnigotto PP et al. 2009 miR-17 family of microRNAs controls FGF10-mediated embryonic lung epithelial branching morphogenesis through MAPK14 and STAT3 regulation of E-cadherin distribution. Developmental Biology 333 238-250.

Castellone MD, Guarino V, De Falco V, Carlomagno F, Basolo F, Faviana P, Kruhoffer M, Orntoft T, Russell JP, Rothstein JL et al. 2004 Functional expression of the CXCR4 chemokine receptor is induced by RET/PTC oncogenes and is a common event in human papillary thyroid carcinomas. Oncogene 23 5958-5967.

Chen J, Jackson PK, Kirschner MW \& Dutta A 1995 Separate domains of p21 involved in the inhibition of Cdk kinase and PCNA. Nature 374 386-388.

Chen YT, Kitabayashi N, Zhou XK, Fahey TJ III \& Scognamiglio T 2008 MicroRNA analysis as a potential diagnostic tool for papillary thyroid carcinoma. Modern Pathology 21 1139-1146.

Ciafrè SA, Galardi S, Mangiola A, Ferracin M, Liu CG, Sabatino G, Negrini M, Maira G, Croce CM \& Farace MG 2005 Extensive modulation of a set of microRNAs in primary glioblastoma. Biochemical and Biophysical Research Communications 334 1351-1358.

Ciampi R, Knauf JA, Kerler R, Gandhi M, Zhu Z, Nikiforova MN, Rabes HM, Fagin JA \& Nikiforov YE 2005 Oncogenic AKAP9-BRAF fusion is a novel mechanism of MAPK pathway activation in thyroid cancer. Journal of Clinical Investigation 115 94-101.

DeLellis RA, Lloyd RV, Heitz PU \& Eng C 2004 Thyroid and parathyroid tumours. In World Health Organization. Classification of Tumours. Pathology and Genetics of Tumours of Endocrine Organs. pp 51-56. Lyon, France: IARC Press.

Dhillon AS \& Kolch W 2004 Oncogenic B-Raf mutations: crystal clear at last. Cancer Cell 5 303-304.

Donghi R, Longoni A, Pilotti S, Michieli P, Della Porta G \& Pierotti MA 1993 Gene p53 mutations are restricted to poorly differentiated and undifferentiated carcinomas of the thyroid gland. Journal of Clinical Investigation 91 1753-1760.

Dwight T, Thoppe SR, Foukakis T, Lui WO, Wallin G, Höög A, Frisk T, Larsson C \& Zedenius J 2003 Involvement of the PAX8/peroxisome proliferator- 
activated receptor gamma rearrangement in follicular thyroid tumors. Journal of Clinical Endocrinology and Metabolism 88 4440-4445.

Elmén J, Lindow M, Schütz S, Lawrence M, Petri A, Obad S, Lindholm M, Hedtjärn M, Hansen $\mathrm{HF}$, Berger U et al. 2008 LNA-mediated microRNA silencing in non-human primates. Nature 452 896-899.

Esapa CT, Johnson SJ, Kendall-Taylor P, Lennard TW \& Harris PE 1999 Prevalence of Ras mutations in thyroid neoplasia. Clinical Endocrinology 50 529-535.

Ezzat S, Zheng L, Kolenda J, Safarian A, Freeman JL \& Asa SL 1996 Prevalence of activating ras mutations in morphologically characterized thyroid nodules. Thyroid 6 409-416.

Fagin JA, Matsuo K, Karmakar A, Chen DL, Tang SH \& Koeffler HP 1993 High prevalence of mutations of the p53 gene in poorly differentiated human thyroid carcinomas. Journal of Clinical Investigation 91 179-184.

Felli N, Fontana L, Pelosi E, Botta R, Bonci D, Facchiano F, Liuzzi F, Lulli V, Morsilli O, Santoro S et al. 2005 MicroRNAs 221 and 222 inhibit normal erythropoiesis and erythroleukemic cell growth via kit receptor downmodulation. PNAS 102 18081-18086.

Fornari F, Gramantieri L, Ferracin M, Veronese A, Sabbioni S, Calin GA, Grazi GL, Giovannini C, Croce CM, Bolondi L et al. 2008 MiR-221 controls CDKN1C/p57 and $\mathrm{CDKN} 1 \mathrm{~B} / \mathrm{p} 27$ expression in human hepatocellular carcinoma. Oncogene 27 5651-5661.

Frattini M, Ferrario C, Bressan P, Balestra D, De Cecco L, Mondellini P, Bongarzone I, Collini P, Gariboldi M, Pilotti S et al. 2004 Alternative mutations of BRAF, RET and NTRK1 are associated with similar but distinct gene expression patterns in papillary thyroid cancer. Oncogene 23 7436-7440.

French CA, Alexander EK, Cibas ES, Nose V, Laguette J, Faquin W, Garber J, Moore F Jr, Fletcher JA, Larsen PR et al. 2003 Genetic and biological subgroups of low-stage follicular thyroid cancer. American Journal of Pathology 162 1053-1060.

Galardi S, Mercatelli N, Giorda E, Massalini S, Frajese GV, Ciafrè SA \& Farace MG 2007 miR-221 and miR-222 expression affects the proliferation potential of human prostate carcinoma cell lines by targeting p27Kip1. Journal of Biological Chemistry 282 23716-23724.

Gallagher WM, Greene LM, Ryan MP, Sierra V, Berger A, Laurent-Puig P \& Conseiller E 2001 Human fibulin-4: analysis of its biosynthetic processing and mRNA expression in normal and tumour tissues. FEBS Letters 489 59-66.

Garcia-Rostan G, Camp RL, Herrero A, Carcangiu ML, Rimm DL \& Tallini G 2001 Beta-catenin dysregulation in thyroid neoplasms: down-regulation, aberrant nuclear expression, and CTNNB1 exon 3 mutations are markers for aggressive tumor phenotypes and poor prognosis. American Journal of Pathology 158 987-996.
Garcia-Rostan G, Costa AM, Pereira-Castro I, Salvatore G, Hernandez R, Hermsem MJ, Herrero A, Fusco A, Cameselle-Teijeiro J \& Santoro M 2005 Mutation of the PIK3CA gene in anaplastic thyroid cancer. Cancer Research 65 10199-10207.

Garofalo M, Quintavalle C, Di Leva G, Zanca C, Romano G, Taccioli C, Liu CG, Croce CM \& Condorelli G 2008 MicroRNA signatures of TRAIL resistance in human nonsmall cell lung cancer. Oncogene 27 3845-3855.

Grieco M, Santoro M, Berlingieri MT, Melillo RM, Donghi R, Bongarzone I, Pierotti MA, Della Porta G, Fusco A \& Vecchio G 1990 PTC is a novel rearranged form of the ret proto-oncogene and is frequently detected in vivo in human thyroid papillary carcinomas. Cell 60 557-563.

Griffiths-Jones S, Grocock RJ, van Dongen S, Bateman A \& Enright AJ 2006 miRBase: microRNA sequences, targets and gene nomenclature. Nucleic Acids Research 34 D140-D144.

Griffiths-Jones S, Saini HK, van Dongen S \& Enright AJ 2008 miRBase: tools for microRNA genomics. Nucleic Acids Research 36 D154-D158.

Gu Y, Turck CW \& Morgan DO 1993 Inhibition of CDK2 activity in vivo by an associated $20 \mathrm{~K}$ regulatory subunit. Nature 366 707-710.

Guan KL, Jenkins CW, Li Y, Nichols MA, Wu X, O'Keefe CL, Matera AG \& Xiong Y 1994 Growth suppression by p18, a p16INK4/MTS1- and p14INK4B/MTS2-related CDK6 inhibitor, correlates with wild-type $\mathrm{pRb}$ function. Genes and Development 8 2939-2952.

Gudmundsson J, Sulem P, Gudbjartsson DF, Jonasson JG, Sigurdsson A, Bergthorsson JT, He H, Blondal T, Geller F, Jakobsdottir M et al. 2009 Common variants on 9q22.33 and $14 q 13.3$ predispose to thyroid cancer in European populations. Nature Genetics 41 460-464.

Hannon GJ, Casso D \& Beach D 1994 KAP: a dual specificity phosphatase that interacts with cyclin-dependent kinases. PNAS 91 1731-1735.

Harach HR, Escalante DA \& Day ES 2002 Thyroid cancer and thyroiditis in Salta, Argentina: a 40-yr study in relation to iodine prophylaxis. Endocrine Pathology 13 175-181.

He H, Jazdzewski K, Li W, Liyanarachchi S, Nagy R, Volinia S, Calin GA, Liu CG, Franssila K, Suster S et al. 2005 The role of microRNA genes in papillary thyroid carcinoma. PNAS 102 19075-19080.

Henson BJ, Bhattacharjee S, O'Dee DM, Feingold E \& Gollin SM 2009 Decreased expression of miR-125b and miR-100 in oral cancer cells contributes to malignancy. Genes, Chromosomes \& Cancer 48 569-582.

Hirai H, Roussel MF, Kato JY, Ashmun RA \& Sherr CJ 1995 Novel INK4 proteins, p19 and p18, are specific inhibitors of the cyclin D-dependent kinases CDK4 and CDK6. Molecular and Cellular Biology 15 2672-2681.

Hou P, Liu D, Shan Y, Hu S, Studeman K, Condouris S, Wang Y, Trink A, El-Naggar AK, Tallini G et al. 2007 
Genetic alterations and their relationship in the phosphatidylinositol 3-kinase/Akt pathway in thyroid cancer. Clinical Cancer Research 13 1161-1170.

Hurst DR, Edmonds MD, Scott GK, Benz CC, Vaidya KS \& Welch DR 2009 Breast cancer metastasis suppressor 1 up-regulates miR-146, which suppresses breast cancer metastasis. Cancer Research 69 1279-1283.

Ito T, Seyama T, Mizuno T, Tsuyama N, Hayashi T, Hayashi Y, Dohi K, Nakamura N \& Akiyama M 1992 Unique association of p53 mutations with undifferentiated but not with differentiated carcinomas of the thyroid gland. Cancer Research 52 1369-1371.

Ito Y, Yoshida H, Tomoda C, Uruno T, Takamura Y, Miya A, Kobayashi K, Matsuzuka F, Kuma K \& Miyauchi A 2005 Telomerase activity in thyroid neoplasms evaluated by the expression of human telomerase reverse transcriptase (hTERT). Anticancer Research 25 509-514.

Jazdzewski K, Murray EL, Franssila K, Jarzab B, Schoenberg DR \& de la Chapelle A 2008 Common SNP in pre-miR-146a decreases mature miR expression and predisposes to papillary thyroid carcinoma. PNAS 105 7269-7274.

Jazdzewski K, Liyanarachchi S, Swierniak M, Pachucki J, Ringel MD, Jarzab B \& de la Chapelle A 2009 Polymorphic mature microRNAs from passenger strand of pre-miR-146a contribute to thyroid cancer. PNAS 106 1502-1505.

Jemal A, Siegel R, Ward E, Hao Y, Xu J, Murray T \& Thun MJ 2008 Cancer statistics, 2008. CA: A Cancer Journal for Clinicians 58 71-96.

Kaldis P 2007 Another piece of the p27Kip1 puzzle. Cell 128 241-244.

Kimura ET, Nikiforova MN, Zhu Z, Knauf JA, Nikiforov YE \& Fagin JA 2003 High prevalence of BRAF mutations in thyroid cancer: genetic evidence for constitutive activation of the RET/PTC-RAS-BRAF signaling pathway in papillary thyroid carcinoma. Cancer Research 63 1454-1457.

Kondo T, Ezzat S \& Asa SL 2006 Pathogenetic mechanisms in thyroid follicular-cell neoplasia. Nature Reviews. Cancer 6 292-306.

Kota J, Chivukula RR, O’Donnell KA, Wentzel EA, Montgomery CL, Hwang HW, Chang TC, Vivekanandan P, Torbenson M, Clark KR et al. 2009 Therapeutic microRNA delivery suppresses tumorigenesis in a murine liver cancer model. Cell 137 1005-1017.

Kroll TG, Sarraf P, Pecciarini L, Chen CJ, Mueller E, Spiegelman BM \& Fletcher JA 2000 PAX8-PPARgamma1 fusion oncogene in human thyroid carcinoma. Science 289 1357-1360.

Labbaye C, Spinello I, Quaranta MT, Pelosi E, Pasquini L, Petrucci E, Biffoni M, Nuzzolo ER, Billi M, Foà R et al. 2008 A three-step pathway comprising PLZF/miR-146a/ CXCR4 controls megakaryopoiesis. Nature Cell Biology 10 788-801.
Ledent C, Dumont J, Vassart G \& Parmentier M 1991 Thyroid adenocarcinomas secondary to tissue-specific expression of simian virus-40 large T-antigen in transgenic mice. Endocrinology 129 1391-1401.

Lindor NM \& Greene MH 1998 The concise handbook of family cancer syndromes. Mayo Familial Cancer Program. Journal of the National Cancer Institute 90 1039-1071.

Liu X, Yu J, Jiang L, Wang A, Shi F, Ye H \& Zhou X 2009 MicroRNA-222 regulates cell invasion by targeting matrix metalloproteinase 1 (MMP1) and manganese superoxide dismutase 2 (SOD2) in tongue squamous cell carcinoma cell lines. Cancer Genomics \& Proteomics 6 131-139.

LiVolsi VA \& Asa SL 1994 The demise of follicular carcinoma of the thyroid gland. Thyroid: Official Journal of the American Thyroid Association 4 233-236.

Lupoli G, Vitale G, Caraglia M, Fittipaldi MR, Abbruzzese A, Tagliaferri P \& Bianco AR 1999 Familial papillary thyroid microcarcinoma: a new clinical entity. Lancet 353 637-639.

McCall KD, Harii N, Lewis CJ, Malgor R, Kim WB, Saji M, Kohn AD, Moon RT \& Kohn LD 2007 High basal levels of functional toll-like receptor 3 (TLR3) and noncanonical Wnt5a are expressed in papillary thyroid cancer and are coordinately decreased by phenylmethimazole together with cell proliferation and migration. Endocrinology 148 4226-4237.

Mitomo S, Maesawa C, Ogasawara S, Iwaya T, Shibazaki M, Yashima-Abo A, Kotani K, Oikawa H, Sakurai E, Izutsu $\mathrm{N}$ et al. 2008 Downregulation of miR-138 is associated with overexpression of human telomerase reverse transcriptase protein in human anaplastic thyroid carcinoma cell lines. Cancer Science 99 280-286.

Miyake N, Maeta H, Horie S, Kitamura Y, Nanba E, Kobayashi K \& Terada T 2001 Absence of mutations in the beta-catenin and adenomatous polyposis coli genes in papillary and follicular thyroid carcinomas. Pathology International 51 680-685.

Motoi N, Sakamoto A, Yamochi T, Horiuchi H, Motoi T \& Machinami R 2000 Role of ras mutation in the progression of thyroid carcinoma of follicular epithelial origin. Pathology, Research and Practice $1961-7$.

Namba H, Rubin SA \& Fagin JA 1990 Point mutations of ras oncogenes are an early event in thyroid tumorigenesis. Molecular Endocrinology 4 1474-1479.

Nasser MW, Datta J, Nuovo G, Kutay H, Motiwala T, Majumder S, Wang B, Suster S, Jacob ST \& Ghoshal K 2008 Down-regulation of micro-RNA-1 (miR-1) in lung cancer. Suppression of tumorigenic property of lung cancer cells and their sensitization to doxorubicininduced apoptosis by miR-1. Journal of Biological Chemistry 283 33394-33405. 
Natali PG, Berlingieri MT, Nicotra MR, Fusco A, Santoro E, Bigotti A \& Vecchio G 1995 Transformation of thyroid epithelium is associated with loss of c-kit receptor. Cancer Research 55 1787-1791.

Nikiforov YE 2002 RET/PTC rearrangement in thyroid tumors. Endocrine Pathology 13 3-16.

Nikiforova MN, Lynch RA, Biddinger PW, Alexander EK, Dorn GW II, Tallini G, Kroll TG \& Nikiforov YE 2003 RAS point mutations and PAX8-PPAR gamma rearrangement in thyroid tumors: evidence for distinct molecular pathways in thyroid follicular carcinoma. Journal of Clinical Endocrinology and Metabolism $\mathbf{8 8}$ 2318-2326.

Nikiforova MN, Tseng GC, Steward D, Diorio D \& Nikiforov YE 2008 MicroRNA expression profiling of thyroid tumors: biological significance and diagnostic utility. Journal of Clinical Endocrinology and Metabolism 93 1600-1608.

Ozen M, Creighton CJ, Ozdemir M \& Ittmann M 2008 Widespread deregulation of microRNA expression in human prostate cancer. Oncogene 27 1788-1793.

Pacifico F, Mauro C, Barone C, Crescenzi E, Mellone S, Monaco M, Chiappetta G, Terrazzano G, Liguoro D, Vito $\mathrm{P}$ et al. 2004 Oncogenic and anti-apoptotic activity of NF-kappa B in human thyroid carcinomas. Journal of Biological Chemistry 279 54610-54619.

Paes JE \& Ringel MD 2008 Dysregulation of the phosphatidylinositol 3-kinase pathway in thyroid neoplasia. Endocrinology and Metabolism Clinics of North America 37 375-387.

Pallante P, Visone R, Ferracin M, Ferraro A, Berlingieri MT, Troncone G, Chiappetta G, Liu CG, Santoro M, Negrini M et al. 2006 MicroRNA deregulation in human thyroid papillary carcinomas. Endocrine-Related Cancer 13 497-508.

Pierotti MA, Bongarzone I, Borrello MG, Mariani C, Miranda C, Sozzi G \& Greco A 1995 Rearrangements of TRK proto-oncogene in papillary thyroid carcinomas. Journal of Endocrinological Investigation 18 130-133.

Polyak K, Lee MH, Erdjument-Bromage H, Koff A, Roberts JM, Tempst P \& Massagué J 1994 Cloning of p27Kip1, a cyclin-dependent kinase inhibitor and a potential mediator of extracellular antimitogenic signals. Cell $\mathbf{7 8}$ 59-66.

Rhoades MW, Reinhart BJ, Lim LP, Burge CB, Bartel B \& Bartel DP 2002 Prediction of plant microRNA targets. Cell 110 513-520.

Ricarte-Filho JC, Ryder M, Chitale DA, Rivera M, Heguy A, Ladanyi M, Janakiraman M, Solit D, Knauf JA, Tuttle RM et al. 2009 Mutational profile of advanced primary and metastatic radioactive iodine-refractory thyroid cancers reveals distinct pathogenetic roles for BRAF, PIK3CA, and AKT1. Cancer Research 69 4885-4893.

Santarpia L, El-Naggar AK, Cote GJ, Myers JN \& Sherman SI 2008 Phosphatidylinositol 3-kinase/akt and ras/raf-mitogen-activated protein kinase pathway mutations in anaplastic thyroid cancer. Journal of Clinical Endocrinology and Metabolism 93 278-284.

Santoro M, Dathan NA, Berlingieri MT, Bongarzone I, Paulin C, Grieco M, Pierotti MA, Vecchio G \& Fusco A 1994 Molecular characterization of RET/PTC3; a novel rearranged version of the RET proto-oncogene in a human thyroid papillary carcinoma. Oncogene 9 509-516.

Santoro M, Papotti M, Chiappetta G, Garcia-Rostan G, Volante M, Johnson C, Camp RL, Pentimalli F, Monaco C, Herrero A et al. 2002 RET activation and clinicopathologic features in poorly differentiated thyroid tumors. Journal of Clinical Endocrinology and Metabolism 87 370-379.

Santoro M, Carlomagno F, Melillo RM \& Fusco A 2004 Dysfunction of the RET receptor in human cancer. Cellular and Molecular Life Sciences 61 2954-2964.

Schulte KM, Jonas C, Krebs R \& Roher HD 2000 Activin A and activin receptors in the human thyroid: a link to the female predominance of goiter? Hormone and Metabolic Research 32 390-400.

Schulte KM, Jonas C, Krebs R \& Roher HD 2001 Activin A and activin receptors in thyroid cancer. Thyroid 11 3-14.

Schwertheim S, Sheu SY, Worm K, Grabellus F \& Schmid KW 2009 Analysis of deregulated miRNAs is helpful to distinguish poorly differentiated thyroid carcinoma from papillary thyroid carcinoma. Hormone and Metabolic Research 41 475-481.

Serrano M, Hannon GJ \& Beach D 1993 A new regulatory motif in cell-cycle control causing specific inhibition of cyclin D/CDK4. Nature 366 704-707.

Soares P, Trovisco V, Rocha AS, Lima J, Castro P, Preto A, Máximo V, Botelho T, Seruca R \& Sobrinho-Simões M 2003 BRAF rearrangements are alternative events in the etiopathogenesis of PTC. Oncogene 22 4578-4580.

Suarez HG, du Villard JA, Severino M, Caillou B, Schlumberger M, Tubiana M, Parmentier C \& Monier R 1990 Presence of mutations in all three ras genes in human thyroid tumors. Oncogene 5 565-570.

Taganov KD, Boldin MP, Chang KJ \& Baltimore D 2006 NF-kappaB-dependent induction of microRNA miR-146, an inhibitor targeted to signaling proteins of innate immune responses. PNAS 103 12481-12486.

Taganov KD, Boldin MP \& Baltimore D 2007 MicroRNAs and immunity: tiny players in a big field. Immunity 26 133-137.

Takakura S, Mitsutake N, Nakashima M, Namba H, Saenko VA, Rogounovitch TI, Nakazawa Y, Hayashi T, Ohtsuru A \& Yamashita S 2008 Oncogenic role of miR-17-92 cluster in anaplastic thyroid cancer cells. Cancer Science 99 1147-1154.

Tang G, Reinhart BJ, Bartel DP \& Zamore PD 2003 A biochemical framework for RNA silencing in plants. Genes and development 17 49-63. 
Tetzlaff MT, Liu A, Xu X, Master SR, Baldwin DA, Tobias JW, Livolsi VA \& Baloch ZW 2007 Differential expression of miRNAs in papillary thyroid carcinoma compared to multinodular goiter using formalin fixed paraffin embedded tissues. Endocrine Pathology 18 163-173.

Vasko VV, Gaudart J, Allasia C, Savchenko V, Di Cristofaro J, Saji M, Ringel MD \& De Micco C 2004 Thyroid follicular adenomas may display features of follicular carcinoma and follicular variant of papillary carcinoma. European Journal of Endocrinology 151 779-786.

Visconti R, Cerutti J, Battista S, Fedele M, Trapasso F, Zeki K, Miano MP, de Nigris F, Casalino L, Curcio F et al. 1997 Expression of the neoplastic phenotype by human thyroid carcinoma cell lines requires NFkappaB p65 protein expression. Oncogene 15 1987-1994.

Visone R, Russo L, Pallante P, De Martino I, Ferraro A, Leone V, Borbone E, Petrocca F, Alder H, Croce CM et al. 2007a MicroRNAs (miR)-221 and miR-222, both overexpressed in human thyroid papillary carcinomas, regulate p27Kip1 protein levels and cell cycle. Endocrine-Related Cancer 14 791-798.

Visone R, Pallante P, Vecchione A, Cirombella R, Ferracin M, Ferraro A, Volinia S, Coluzzi S, Leone V, Borbone E et al.
$2007 b$ Specific microRNAs are downregulated in human thyroid anaplastic carcinomas. Oncogene $\mathbf{2 6}$ 7590-7595.

Volinia S, Calin GA, Liu CG, Ambs S, Cimmino A, Petrocca F, Visone R, Iorio M, Roldo C, Ferracin M et al. 2006 A microRNA expression signature of human solid tumors defines cancer gene targets. PNAS 103 2257-2261.

Weber F, Teresi RE, Broelsch CE, Frilling A \& Eng C 2006 A limited set of human microRNA is deregulated in follicular thyroid carcinoma. Journal of Clinical Endocrinology and Metabolism 91 3584-3591.

Williams D 2002 Cancer after nuclear fallout: lessons from the Chernobyl accident. Nature Reviews. Cancer 2 543-549.

Yau T, Lo CY, Epstein RJ, Lam AK, Wan KY \& Lang BH 2008 Treatment outcomes in anaplastic thyroid carcinoma: survival improvement in young patients with localized disease treated by combination of surgery and radiotherapy. Annals of Surgical Oncology 15 2500-2505.

Zhu H, Wu H, Liu X, Li B, Chen Y, Ren X, Liu CG \& Yang JM 2009 Regulation of autophagy by a beclin 1-targeted microRNA, miR-30a, in cancer cells. Autophagy $\mathbf{5}$ 816-823. 